\title{
Corona-Krise, Inflationsziel der EZB und Inflationsmessung
}

Die EZB plant ebenso wie die US-amerikanische Federal Reserve, ihr Inflationsziel leicht auf $2 \%$ anzuheben und dies im Durchschnitt mehrerer Jahre zu erreichen. Tatsächlich liegt die Inflationsrate aber trotz der sehr lockeren Geldpolitik deutlich unter $2 \%$. Werden die Maßnahmen gegen die Corona-Krise die Preissteigerung erhöhen? Während der Finanzkrise war es nicht dazu gekommen. Auch die derzeit erwartete Wirtschaftsentwicklung spricht nicht für hohe Preissteigerungen. Aber welche Rate sollte als Indikator für die „wahre“ Inflation gemessen werden? Sollten die Vermögenspreise berücksichtigt werden? Was spricht für den BIP-Deflator, was für den Konsumentenpreisindex? Wie ist eine hedonische Qualitätsbereinigung zu bewerten? Über diese Fragen diskutieren die Teilnehmer*innen des Zeitgesprächs.

\section{Kommt nach der Corona-Krise die Inflation?}

Peter Bofinger, Julius-Maximilians-Universität Würzburg.

Ein höheres Inflationsziel für die EZB?

Bernhard Herz, Universität Bayreuth.

Lukas Menkhoff, Humboldt-Universität zu Berlin; DIW Berlin.

Inflation, Inflationsmessung und Zentralbankpolitik

Alfons Weichenrieder, Goethe-Universität Frankfurt am Main; WU Wien; Leibniz Institut SAFE.

Eren Gürer, Goethe-Universität Frankfurt am Main.

Die Inflationsmessung erzeugt die Illusion der stabilen Kaufkraft

Gunther Schnabl, Universität Leipzig.

Wird die „wahre“ Inflationsrate gemessen? - Praxis der Inflationsmessung vor dem Hintergrund der Corona-Pandemie

Susanne Hagenkort-Rieger, Statistisches Bundesamt, Wiesbaden.

\footnotetext{
Title: The Coronavirus Crisis, the Inflation Target of the ECB and Inflation Measurement
}

Abstract: The ECB is discussing how to raise its inflation target slightly to $2 \%$, just as the US Federal Reserve is raising it slightly and aiming to achieve it over several years on average. In reality, however, the inflation rate is well below $2 \%$ despite the very relaxed monetary policy. Will the measures against the corona crisis increase the inflation rate? This did not happen during the financial crisis despite the increase in the money supply. Even current economic developments do not explain the high price increases. So what rate should be measured as an indicator of "true" inflation? Should asset prices be taken into account? What about the GDP deflator, or the consumer price index? How should a hedonic quality adjustment be assessed? These are the questions that Zeitgespräch participants will discuss.

JEL Classification: E31,E40, E50 